\title{
Prevalence of coronary heart disease, left ventricular failure and hypertension in middle-aged, newly diagnosed Type 2 (non-insulin-dependent) diabetic subjects
}

\author{
M. Uusitupa, O. Siitonen, A. Aro and K. Pyörälä \\ Department of Medicine, University Central Hospital of Kuopio, Kuopio, Finland
}

\begin{abstract}
Summary. The prevalence of coronary heart disease, left ventricular failure and hypertension was examined in a representative group of 133 newly diagnosed Type 2 (non-insulin-dependent) diabetic subjects ( $70 \mathrm{men}, 63$ women), aged 45 to 64 years, and in a group of 144 randomly selected non-diabetic control subjects ( $62 \mathrm{men}, 82$ women) of the same age group. The prevalence of previous myocardial infarction (major QQS abnormalities in resting ECG and/or myocardial infarction verified at hospital) was increased 1.7-fold in male (NS) and 4.4-fold in female $(p=0.007)$ diabetic patients compared with that found in non-diabetic subjects. Chest pain symptoms and ischaemic ECG abnormalities were about twice as common among diabetic than among non-diabetic subjects. The frequency of coronary heart disease defined by chest pain
\end{abstract}

symptoms and ECG abnormalities was 3.5 times higher in male $(p=0.001)$ and 3.1 times higher in female $(p=0.001)$ diabetic patients than in the respective non-diabetic subjects. The frequency of current digitalis therapy was increased 3.3-fold in male $(p=0.006)$ and 3.9-fold in female $(p=0.001)$ diabetic patients suggesting an increased frequency of left ventricular failure among diabetic subjects. The prevalence of hypertension, based on the elevated blood pressure levels and/or current use of antihypertensive drugs, was increased 1.6-1.7-fold among the diabetic patients.

Key words: Type 2 diabetes, coronary heart disease, left ventricular failure, hypertension.

diagnosed diabetic patients have shown higher blood pressure levels than non-diabetic subjects, whereas previously diagnosed diabetic patients have not differed from non-diabetic subjects in this respect $[3,18,19]$.

We therefore examined the prevalence of CHD, left ventricular failure and hypertension in a representative group of newly diagnosed Type 2 diabetic patients and in a randomly selected non-diabetic control population of similar age.

\section{Subjects and methods}

becomes clinically manifest. Thus it is conceivable that this type of diabetes might be associated with an increased occurrence of CHD at the time of diagnosis. Two studies $[11,12]$ have already shown that symptoms, or ECG abnormalities suggestive of CHD, are more common at the time of diagnosis in middle-aged diabetic than in non-diabetic subjects of the same age.

Congestive heart failure has also been shown to be more common among middle-aged diabetic subjects than in the non-diabetic population [13], but no data are available concerning the frequency of this disease in newly diagnosed diabetic patients.

In most studies hypertension has been found to be more common in diabetic patients predominantly with Type 2 diabetes than in the non-diabetic population [14-17]. However, in some of these reports, only newly

\begin{abstract}
Subjects
The study population consisted of 133 newly diagnosed Type 2 diabetic subjects, aged 45-64 years at the time of diagnosis, and 144 randomly selected non-diabetic subjects in the same age-group, investigated between 1 May 1979 and 31 December 1981. Both groups were collected from a defined area of 180,000 inhabitants in the county of Kuopio in Eastern Finland.

Approval for the study has been given by the Ethical Committee of the University of Kuopio. Informed consent was given by all subjects studied.

Newly diagnosed diabetic patients. General practitioners working in community health centres and private practitioners in the survey area were asked to refer newly-diagnosed diabetic patients with a fasting venous whole blood glucose $\geqslant 7.0 \mathrm{mmol} / \mathrm{l}$, aged $45-64$ years, to the outpatient department of Kuopio University Central Hospital. All
\end{abstract}


Table 1. Details of the study population

\begin{tabular}{llllll}
\hline $\begin{array}{l}\text { Age groups } \\
\text { (years) }\end{array}$ & Men & & \multicolumn{2}{l}{ Women } \\
\cline { 2 - 3 } \cline { 5 - 6 } & $\begin{array}{l}\text { Diabetic } \\
\text { subjects }\end{array}$ & $\begin{array}{l}\text { Control } \\
\text { subjects }\end{array}$ & & $\begin{array}{l}\text { Diabetic } \\
\text { subjects }\end{array}$ & $\begin{array}{l}\text { Control } \\
\text { subjects }\end{array}$ \\
\hline $45-49$ & 15 & 21 & 5 & 16 \\
$50-54$ & 16 & 19 & 13 & 30 \\
$55-59$ & 21 & 14 & 22 & 14 \\
$60-64$ & 18 & 8 & 23 & 22 \\
Total & 70 & 62 & 63 & 82 \\
\hline Mean \pm SD age & $54.8 \pm 5.7$ & $52.9 \pm 5.1$ & $57.1 \pm 5.1$ & $54.3 \pm 5.6$ \\
& \multicolumn{3}{c}{$p<0.001$} & & $p<0.001$ \\
\hline
\end{tabular}

Table 2. Anthropometric characteristics in diabetic and control subjects

\begin{tabular}{|c|c|c|}
\hline \multirow[t]{2}{*}{ Variable } & Men & Women \\
\hline & $\begin{array}{ll}\text { Diabetic } & \text { Control } \\
\text { subjects } & \text { subjects } \\
(n=70) & (n=62)\end{array}$ & $\begin{array}{ll}\text { Diabetic } & \text { Control } \\
\text { subjects } & \text { subjects } \\
(n=63) & (n=82)\end{array}$ \\
\hline $\begin{array}{c}\text { Height }(\mathrm{cm}) \\
\text { ANOVA }\end{array}$ & $\begin{array}{cc}172.4 \pm 5.9 & 172.7 \pm 7.1 \\
\text { Group } & p=0.896 \\
\text { Age } \quad p=0.327\end{array}$ & $\begin{array}{cl}157.2 \pm 5.6 & 158.5 \pm 5.4 \\
\text { Group } & p=0.144 \\
\text { Age } & p=0.981\end{array}$ \\
\hline $\begin{array}{c}\text { Weight (kg) } \\
\text { ANOVA }\end{array}$ & $\begin{array}{ll}88.6 \pm 16.7 & 80.1 \pm 11.8 \\
\text { Group } & p<0.0001 \\
\text { Age } & p=0.134\end{array}$ & $\begin{array}{cl}77.3 \pm 14.3 & 68.3 \pm 11.8 \\
\text { Group } & p<0.0001 \\
\text { Age } & p=0.398\end{array}$ \\
\hline $\begin{array}{l}\text { Body mass } \\
\text { index }\left(\mathrm{kg} / \mathrm{m}^{2}\right) \\
\text { ANOVA }\end{array}$ & $\begin{array}{ll}29.7 \pm 5.0 & 26.9 \pm 3.1 \\
\text { Group } & p<0.0001 \\
\text { Age } & p=0.330\end{array}$ & $\begin{array}{ll}31.3 \pm 5.6 & 27.2 \pm 4.5 \\
\text { Group } & p<0.0001 \\
\text { Age } & p=0.398\end{array}$ \\
\hline
\end{tabular}

Results are expressed as mean $\pm \mathrm{SD}$. ANOVA $=$ analysis of variance

Table 3. Use of digitalis, diuretics, beta-blocking agents and other antihypertensive drugs in diabetic and control subjects

\begin{tabular}{|c|c|c|c|c|}
\hline \multirow[t]{2}{*}{ Drug } & \multicolumn{2}{|l|}{ Men } & \multicolumn{2}{|l|}{ Women } \\
\hline & $\begin{array}{l}\text { Diabetic } \\
\text { subjects } \\
(n=70)\end{array}$ & $\begin{array}{l}\text { Control } \\
\text { subjects } \\
(n=62)\end{array}$ & $\begin{array}{l}\text { Diabetic } \\
\text { subjects } \\
(n=63)\end{array}$ & $\begin{array}{l}\text { Control } \\
\text { subjects } \\
(n=82)\end{array}$ \\
\hline \multirow[t]{2}{*}{ Digitalis } & $20(26)$ & $4(8)$ & $27(31)$ & $6(8)$ \\
\hline & \multicolumn{2}{|c|}{$p=0.006$} & \multicolumn{2}{|c|}{$p=0.001$} \\
\hline \multirow[t]{2}{*}{ Diuretics } & $23(32)$ & $6(11)$ & $32(46)$ & $18(23)$ \\
\hline & \multicolumn{2}{|c|}{$p=0.004$} & \multicolumn{2}{|c|}{$p=0.003$} \\
\hline \multirow{2}{*}{$\begin{array}{l}\text { Beta-blocking } \\
\text { agents }\end{array}$} & $29(40)$ & $10(18)$ & $23(32)$ & $11(14)$ \\
\hline & \multicolumn{2}{|c|}{$p=0.005$} & \multicolumn{2}{|c|}{$p=0.006$} \\
\hline \multirow{2}{*}{$\begin{array}{l}\text { Other anti- } \\
\text { hypertensive } \\
\text { drugs }\end{array}$} & $11(15)$ & $3(5)$ & $9(16)$ & $8(10)$ \\
\hline & \multicolumn{2}{|l|}{ NS } & \multicolumn{2}{|l|}{ NS } \\
\hline
\end{tabular}

Age-adjusted prevalence with percentage given in parentheses

patients were examined within 4 weeks of the detection of diabetes. Whenever necessary, those with hyperglycaemic symptoms were admitted to hospital immediately after diagnosis.

The diagnosis of diabetes was confirmed by an oral glucose tolerance test using the diagnostic criteria recommended by the World Health Organisation (20), i.e. fasting venous whole blood glucose $\geqslant 7.0 \mathrm{mmol} / 1$ and $/$ or 2 -h blood glucose $\geqslant 10 \mathrm{mmol} / 1$.

Patients with secondary diabetes and those whose fasting blood glucose had exceeded $7.0 \mathrm{mmol} / 1$ for more than 6 months were excluded. All patients were non-ketotic at the time of diagnosis and none needed insulin treatment during the follow-up period of at least 3 months from diagnosis.

Of the 144 diabetic patients referred to the study, 11 were excluded. Five did not fulfil the diagnostic criteria of diabetes, one had hypothyroidism, three were outside the age limits and two failed to complete the study. Thus 133 subjects were included in this report (Table 1).

Control subjects. A random control population sample, aged 45-64 years, was selected from the population registers of the study area by using random number tables, taking into account the distribution of the population living in rural and urban communities. Of 183 subjects originally contacted, nine had diabetes, one had hypothyroidism and 29 refused to participate in the study. Thus the final control population consisted of 144 non-diabetic subjects (Table 1).

Both male and female diabetic subjects were, on an average, 2-3 years older than the corresponding non-diabetic subjects due to the fact that the incidence of Type 2 diabetes increases with age. In comparison of the diabetic and non-diabetic subjects, the effect of age was controlled by statistical methods.

During the course of the study, it soon became evident that not all newly diagnosed diabetic patients fulfilling the criteria were being recruited into the study. This information was obtained from a separate survey in which all medical records of the health centres in ten communities of the survey area were reviewed in 1980 for the identification of subjects with diabetes [21], yielding information concerning the time of diagnosis, diagnostic criteria, the mode of treatment and the prevalence of angina pectoris, hypertension, and congestive heart failure. From these data, it was estimated that about $30 \%$ of all diabetic subjects fulfilling the criteria had been recruited for the present study. Nevertheless, the diabetic subjects included did not differ significantly from those not included with respect to the prevalence of cardiovascular diseases or distribution by age and sex [22]. Thus we believe that the group studied is representative of newly diagnosed Type 2 diabetic subjects in the defined age group.

\section{Methods}

Medical history included a history of cardiovascular, renal and any other significant chronic disease and the use of drugs with particular emphasis on the use of cardiovascular drugs. Chest pain symptoms suggestive of CHD were recorded in an interview using the questionnaire developed by Rose [23].

Anthropometric measurements. Standing height was measured without shoes and read to the nearest $0.5 \mathrm{~cm}$. Body weight was measured with an electrical weighing machine (Seca, Modell 708, Hamburg, FRG) with the subjects barefoot and dressed in shorts. Body mass index was calculated (body weight $(\mathrm{kg}) /$ height $\left.(\mathrm{m})^{2}\right)$.

Blood pressure was measured in the sitting position after a 5-min rest with a mercury sphygmomanometer (cuff size $12.5 \times 40.0 \mathrm{~cm}$ ). Systolic and diastolic blood pressures were read to the nearest $2 \mathrm{mmHg}$. Disappearance of Korotkoff sounds (phase V) was used for diastolic blood pressure. Hypertension was diagnosed as a blood pressure level (systolic blood pressure $\geqslant 160 \mathrm{mmHg}$ or diastolic blood pressure $\geqslant 95 \mathrm{mmHg}$ ) [24], and/or the history of antihypertensive drug treatment. Use of the two criteria is specified in the text and tables.

Resting electrocardiography. A conventional 12-lead resting ECG was recorded from each subject, and interpreted according to the Minnesota code $(\mathrm{Mc})$ [25].

Exercise electrocardiography was performed in the sitting position on an electrically braked bicycle ergometer (Mingograph 8, ElemaSchönander, Solna, Sweden) starting at a work load of $50 \mathrm{~W}$. The work load was increased stepwise by $50 \mathrm{~W}$ at 4 -min intervals. The exercise test was continued until $85 \%$ of the predicted maximum heart rate was attained or to the subjective maximum. An ST segment depression of $\geqslant 1 \mathrm{~mm} 0.08 \mathrm{~s}$ after the end of the QRS-complex during or after exercise was regarded as pathological. 
Chest $X$-ray examination. From chest X-ray films analyzed without knowledge of clinical status, the heart volume related to the body surface area $\left(\mathrm{m}^{2}\right)$ was calculated [26] and the signs of left ventricular failure in the pulmonary circulation, i. e. pulmonary venous congestion, interstitial oedema or alveolar oedema, were recorded.

Oral glucose tolerance test. A 75-g oral glucose tolerance test was performed. Whole venous blood glucose samples were taken in fasting condition before the test (fasting) and at 1 and $2 \mathrm{~h}$ and determined using a glucose oxidase method (Glox, Kabi, Stockholm, Sweden).

Classification for the diagnosis of coronary heart disease. Angina pectoris; all chest pain symptoms suggestive of CHD (angina pectoris, and/or severe chest pain attack and/or myocardial infarction verified at hospital); Q-QS abnormalities (Mc 1.1-3); all ischaemic ECG abnormalities (Mc 1.1-3; 4.1-3, 5.1-3 and 7.1) including in addition to Q-QS abnormalities, various degrees of ST segment depression, T wave changes and left bundle branch block. Ischaemic ECG abnormalities are consistent with Whitehall Criteria ECG abnormalities [27]; "definite myocardial infarction". This class consisted of subjects with major Q-QS abnormalities (Mc 1.1-2) and/or subjects who had suffered from myocardial infarction verified at hospital; coronary heart disease by symptoms and ECG. This class was formed to include subjects with some of the CHD symptoms (angina pectoris or severe chest pain attack or myocardial infarction verified at hospital) and some of the ECG abnormalities (Mc 1.1-3, 4.1-3, 5.1-3, 7.1 and/ or ischaemic ST segment depression on exercise test) suggestive of CHD.

\section{Statistical methods}

Age adjustment was carried out by the direct standardization method, using the Finnish male and female population of the age group $45-64$ years in 1980 as the standard population. The significance of differences between the adjusted rates were analyzed by a test of proportions based on standardized normal distribution [28]. Analysis of variance (ANOVA) was used in the statistical analyses of differences between groups concerning continuous variables and for controlling for the effect of age. Two way interactions between the variables are indicated in statistical results only when the p-value of the interaction is $\leqslant 0.10$. A probability level of less than 0.05 was considered statistically significant.

\section{Results}

\section{Anthropometric characteristics and blood glucose level}

Body weight and body mass index were significantly greater in diabetic patients of both sexes than in the respective non-diabetic subjects (Table 2). The mean $( \pm S D)$ actual fasting blood glucose levels for male and female diabetic subjects were $10.3 \pm 3.3$ and $11.2 \pm$ $4.0 \mathrm{mmol} / 1$ and for male and female control subjects $5.1 \pm 0.8$ and $4.8 \pm 0.9 \mathrm{mmol} / 1$, respectively.

\section{Use of cardiovascular drugs}

The use of digitalis was 3.3 times more frequent in male diabetic subjects $(p=0.006)$ and 3.9 times more frequent in female diabetic subjects $(p=0.001)$ than in the respective non-diabetic subjects (Table 3 ).

Diabetic subjects of both sexes were more frequently treated with a diuretic, and a higher proportion of male as well as female diabetic subjects received a betablocking agent compared with the corresponding non-
Table 4. Prevalence of coronary heart disease as assessed by different criteria in diabetic and control subjects

\begin{tabular}{|c|c|c|c|c|}
\hline \multirow[t]{2}{*}{ Prevalence of: } & \multicolumn{2}{|l|}{ Men } & \multicolumn{2}{|l|}{ Women } \\
\hline & $\begin{array}{l}\text { Diabetic } \\
\text { subjects } \\
(n=70)\end{array}$ & $\begin{array}{l}\text { Control } \\
\text { subjects } \\
(n=62)\end{array}$ & $\begin{array}{l}\text { Diabetic } \\
\text { subjects } \\
(n=63)\end{array}$ & $\begin{array}{l}\text { Control } \\
\text { subjects } \\
(n=82)\end{array}$ \\
\hline \multirow[t]{2}{*}{ Angina pectoris } & $32(44)$ & $11(19)$ & $29(43)$ & $18(20)$ \\
\hline & \multicolumn{2}{|c|}{$p=0.002$} & \multicolumn{2}{|c|}{$p=0.003$} \\
\hline \multirow{2}{*}{$\begin{array}{l}\text { All chest pain } \\
\text { symptoms }\end{array}$} & $34(46)$ & $12(21)$ & $32(48)$ & $20(24)$ \\
\hline & \multicolumn{2}{|c|}{$p=0.002$} & \multicolumn{2}{|c|}{$p=0.002$} \\
\hline Minnesota code & $14(17)$ & $6(10)$ & $12(23)$ & $9(11)$ \\
\hline $\begin{array}{l}\text { ECG abnor- } \\
\text { malities 1.1-3 }\end{array}$ & \multicolumn{2}{|l|}{ NS } & \multicolumn{2}{|l|}{ NS } \\
\hline All ischaemic & $38(53)$ & $13(21)$ & $40(59)$ & $32(38)$ \\
\hline $\begin{array}{l}\text { ECG abnor- } \\
\text { malities }\end{array}$ & \multicolumn{2}{|c|}{$p<0.001$} & \multicolumn{2}{|c|}{$p=0.02$} \\
\hline Definite & $13(17)$ & $5(10)$ & $11(18)$ & 4 (4) \\
\hline $\begin{array}{l}\text { myocardial } \\
\text { infarction }\end{array}$ & \multicolumn{2}{|l|}{ NS } & \multicolumn{2}{|c|}{$p=0.007$} \\
\hline \multirow{2}{*}{$\begin{array}{l}\text { Coronary heart } \\
\text { disease by } \\
\text { symptoms and } \\
\text { ECG abnor- } \\
\text { malities }\end{array}$} & $23(32)$ & $5(9)$ & $28(42)$ & $12(14)$ \\
\hline & \multicolumn{2}{|c|}{$p=0.001$} & \multicolumn{2}{|c|}{$p=0.001$} \\
\hline
\end{tabular}

Age-adjusted prevalence with percentage given in parentheses

diabetic subjects. The use of other antihypertensive drugs was also somewhat more frequent among diabetic than non-diabetic subjects, although the differences were not statistically significant (Table 3 ).

\section{Prevalence of coronary heart disease}

The prevalence of angina pectoris and all chest pain symptoms suggestive of CHD was about twice as high in male and female diabetic patients as in the respective normal subjects (Table 4). No sex differences were found in the frequency of angina pectoris or chest pain symptoms.

The prevalence of Q-QS abnormalities (Minnesota code 1.1-3) also tended to be higher in the diabetic patients (Table 4). The frequency of ischaemic ECG abnormalities (Mc 1.1-3, 4.1-3, 5.1-3, 7.1) was increased 2.5 -fold in male $(p<0.01)$ and 1.6 -fold in female diabetic patients $(p=0.02)$.

The prevalence of definite myocardial infarction was increased 1.7-fold in male (NS) and 4.4-fold in female $(p=0.007)$ diabetic patients (Table 4$)$. The prevalence of CHD by symptoms and ECG was increased 3.5 times in male $(p=0.001)$ and 3.1 times in female $(p=0.001)$ diabetic patients (Table 4). The prevalence of CHD by symptoms and ECG was also analyzed by the use of diuretics. The age-adjusted prevalence of CHD was higher in both male $(25 \% ; p=0.013)$ and female $(32 \% ; p=0.003)$ diabetic subjects not taking a diuretic compared with male $(7 \%)$ and female $(8 \%)$ non-diabetic subjects also not taking a diuretic. No significant differ- 
Table 5. Blood pressures and prevalence of hypertension according to different criteria in diabetic and control subjects

\begin{tabular}{|c|c|c|c|c|}
\hline \multirow[t]{2}{*}{ Variable } & \multicolumn{2}{|l|}{ Men } & \multicolumn{2}{|l|}{ Women } \\
\hline & $\begin{array}{l}\text { Diabetic } \\
\text { subjects } \\
(n=70)\end{array}$ & $\begin{array}{l}\text { Control } \\
\text { subjects } \\
(n=62)\end{array}$ & $\begin{array}{l}\text { Diabetic } \\
\text { subjects } \\
(n=63)\end{array}$ & $\begin{array}{l}\text { Control } \\
\text { subjects } \\
(n=82)\end{array}$ \\
\hline $\begin{array}{l}\text { Systolic blood } \\
\text { pressure } \\
(\mathrm{mmHg})\end{array}$ & $147 \pm 17$ & $146 \pm 16$ & $154 \pm 16$ & $147 \pm 18$ \\
\hline ANOVA & $\begin{array}{l}\text { Group } \\
\text { Age }\end{array}$ & $\begin{array}{l}p=0.615 \\
p=0.021\end{array}$ & $\begin{array}{l}\text { Group } \\
\text { Age }\end{array}$ & $\begin{array}{l}p=0.141 \\
p=0.484\end{array}$ \\
\hline $\begin{array}{l}\text { Diastolic blood } \\
\text { pressure } \\
(\mathrm{mmHg})\end{array}$ & $93 \pm 8$ & $91 \pm 8$ & $92 \pm 8$ & $90 \pm 9$ \\
\hline ANOVA & $\begin{array}{l}\text { Group } \\
\text { Age }\end{array}$ & $\begin{array}{l}p=0.275 \\
p=0.983\end{array}$ & $\begin{array}{l}\text { Group } \\
\text { Age }\end{array}$ & $\begin{array}{l}p=0.131 \\
p=0.234\end{array}$ \\
\hline $\begin{array}{l}\text { Prevalence of } \\
\text { hypertension }^{\mathrm{a}}\end{array}$ & $38(55)$ & $\begin{array}{r}26(37) \\
p=0.038\end{array}$ & $27(43)$ & $\begin{array}{r}29(35) \\
p=0.126\end{array}$ \\
\hline $\begin{array}{l}\text { Drug treatment } \\
\text { for hyper- } \\
\text { tension }\end{array}$ & $29(41)$ & $\begin{array}{r}11(18) \\
p=0.005\end{array}$ & $39(60)$ & $\begin{array}{r}19(24) \\
p<0.001\end{array}$ \\
\hline $\begin{array}{c}\text { Combined } \\
\text { criteria }^{\mathrm{b}}\end{array}$ & $43(63)$ & $\begin{array}{r}23(38) \\
p=0.005\end{array}$ & $44(70)$ & $\begin{array}{r}34(42) \\
p=0.002\end{array}$ \\
\hline
\end{tabular}

Results are expressed as mean \pm SD. Age-adjusted prevalence of hypertension with percentage given in parentheses.

a Systolic blood pressure $\geqslant 160 \mathrm{mmHg}$ or diastolic blood pressure $\geqslant 95 \mathrm{mmHg}$; ${ }^{b}$ Systolic blood pressure $\geqslant 160 \mathrm{mmHg}$ or diastolic blood pressure $\geqslant 95 \mathrm{mmHg}$ or drug treatment for hypertension

ences were found in the frequency of CHD between diabetic and non-diabetic subjects treated with diuretics.

\section{Blood pressure level and prevalence of hypertension}

The mean systolic and diastolic blood pressure levels in diabetic subjects did not differ significantly from those in non-diabetic subjects. According to all criteria used, male diabetic subjects had higher prevalence of hypertension than male non-diabetic subjects. Female diabetic subjects showed also higher prevalence of hypertension compared with female non-diabetic subjects when the diagnosis was based on the current anti-hypertensive drug treatment or combined criteria. However, using either high systolic or diastolic blood pressure levels as criteria, the difference between diabetic and non-diabetic women was not statistically significant (Table 5).

\section{Relationship of body mass index to cardiovascular diseases}

The prevalence of digitalis therapy, coronary heart disease and hypertension was also analyzed in two body mass index groups. This analysis showed that the higher frequency of the use of digitalis, coronary heart disease and hypertension among diabetic subjects could not be ascribed solely to the higher degree of obesity (Table 6).
Table 6. Use of digitalis and the prevalence of coronary heart disease and hypertension in diabetic and control subjects according to the degree of obesity

\begin{tabular}{|c|c|c|c|c|}
\hline & \multicolumn{4}{|c|}{ Age-adjusted prevalence $(\%)$} \\
\hline & \multicolumn{2}{|l|}{ Men } & \multicolumn{2}{|l|}{ Women } \\
\hline & $\begin{array}{l}\text { Diabetic } \\
\text { subjects }\end{array}$ & $\begin{array}{l}\text { Control } \\
\text { subjects }\end{array}$ & $\begin{array}{l}\text { Diabetic } \\
\text { subjects }\end{array}$ & $\begin{array}{l}\text { Control } \\
\text { subjects }\end{array}$ \\
\hline $\begin{array}{l}\text { Body mass } \\
\text { index }>28 \mathrm{~kg} / \mathrm{m}^{2}\end{array}$ & $(n=39)$ & $(n=20)$ & $(n=47)$ & $(n=27)$ \\
\hline Use of digitalis & \multicolumn{2}{|c|}{$p=0.069$} & \multicolumn{2}{|c|}{$p=0.009$} \\
\hline $\begin{array}{l}\text { Prevalence of } \\
\text { coronary heart } \\
\text { disease by } \\
\text { symptoms and } \\
\text { ECG }\end{array}$ & \multicolumn{2}{|c|}{$p=0.003$} & \multicolumn{2}{|c|}{$p=0.0146$} \\
\hline $\begin{array}{l}\text { Prevalence of } \\
\text { hypertension } \\
\text { (combined cri- } \\
\text { terial) }\end{array}$ & \multicolumn{2}{|c|}{$p=0.0146$} & \multicolumn{2}{|c|}{$p=0.134$} \\
\hline $\begin{array}{l}\text { Body mass index } \\
<28 \mathrm{~kg} / \mathrm{m}^{2}\end{array}$ & $(n=31)$ & $(n=42)$ & $(n=16)$ & $(n=55)$ \\
\hline Use of digitalis & $17 \quad p=$ & & $21 \quad p=$ & $5^{5}$ \\
\hline $\begin{array}{l}\text { Prevalence of } \\
\text { coronary heart } \\
\text { disease by } \\
\text { symptoms and } \\
\text { ECG }\end{array}$ & \multicolumn{2}{|c|}{$p=0.027$} & \multicolumn{2}{|c|}{$p=0.097$} \\
\hline $\begin{array}{l}\text { Prevalence of } \\
\text { hypertension } \\
\text { (combined cri- } \\
\text { teria) }\end{array}$ & \multicolumn{2}{|c|}{$p=0.68$} & \multicolumn{2}{|c|}{$p=0.06$} \\
\hline
\end{tabular}

\section{Radiological findings}

Relative heart volume was $465 \pm 100 \mathrm{ml} / \mathrm{m}^{2}$ in male diabetic patients and $431 \pm 79 \mathrm{ml} / \mathrm{m}^{2}$ in male non-diabetic subjects $(p=0.108)$, and $394 \pm 71$ and $381 \pm 99 \mathrm{ml} / \mathrm{m}^{2}$ $(p=0.754)$ in female diabetic and non-diabetic subjects, respectively. The prevalence of cardiomegaly (relative heart volume $\geqslant 500 \mathrm{ml} / \mathrm{m}^{2}$ for men and $\geqslant 450 \mathrm{ml} / \mathrm{m}^{2}$ for women) was $34 \%$ in male diabetic and $16 \%$ in male non-diabetic subjects (NS) and $18 \%$ and $12 \%$ in female diabetic and non-diabetic subjects (NS), respectively. Radiological signs of pulmonary venous congestion, indicating manifest left ventricular failure, were found in four male and three female diabetic and one male and two female non-diabetic subjects. Both diabetic as well as non-diabetic subjects receiving digitalis showed significantly larger heart volumes than the corresponding subjects not using digitalis.

\section{Discussion}

Essential questions in the interpretation of the present results is how representative the group of newly-diagnosed diabetic subjects was and how adequate was the 
selection of non-diabetic control subjects. The representativeness was evaluated by comparing some characteristics of the diabetic subjects included in the study with that of diabetic subjects fulfilling the criteria, but not included. According to the available data, the diabetic subjects in the present study did not differ significantly from those not included with regard to the prevalence of cardiovascular diseases or distribution by age and sex. There does not therefore appear to be any indication of selective bias in the formation of the diabetic study group. However it is difficult to exclude the possibility that some excess of cardiovascular disease in diabetic subjects of the present study could have been due to the fact that a coexistent cardiovascular disease might have lead to the detection of diabetes. In addition, because the diagnosis of diabetes in the present study was primarily made in a clinical setting, and not by a screening of a defined population, asymptomatic diabetic subjects were not included in the present diabetic group. It has however been shown, that asymptomatic diabetes subjects, diagnosed by an oral glucose tolerance test in population studies, also have an increased frequency of ischaemic ECG abnormalities and clinical symptoms of CHD [11].

Non-diabetic subjects selected from the population registers of the survey area did not differ essentially from other Finnish population groups of similar age with respect to anthropometric characteristics or to the occurrence of CHD symptoms, ECG abnormalities or hypertension [29-31].

In the present study newly diagnosed diabetic patients showed a higher frequency of CHD than non-diabetic subjects. The prevalence of a previous definite myocardial infarction was 1.7 times higher in male diabetic and 4.4 times higher in female diabetic subjects than in the respective non-diabetic groups. When the presence of CHD was defined by symptoms and ECG, there was about a threefold increase in frequency of CHD in diabetic subjects of both sexes. In agreement with two previous studies on middle-aged newly diagnosed diabetic patients $[11,12]$, both chest pain symptoms and ECG abnormalities were found to be substantially more common in diabetic than in non-diabetic subjects.

The frequency of a previous definite myocardial infarction was virtually similar in both sexes of diabetic subjects. In this respect the present results are in accordance with prospective studies on diabetic subjects $[1,2$, $5,6]$, showing a greater relative excess of CHD morbidity in diabetic women than in diabetic men; compared with non-diabetic subjects.

The high prevalence of CHD in Type 2 diabetic subjects at the time of diagnosis suggests that the increased morbidity from this cause may not be greatly dependent on the duration of diabetes. In addition they are compatible with studies in which an increased frequency of CHD has been seen in groups with impaired glucose tolerance $[4,6,8]$.

As expected, diabetic subjects were more obese than non-diabetic subjects, but this did not account for the higher prevalence of CHD among diabetic patients. Diuretic therapy, which may impair glucose tolerance [32], was also more common in diabetic than in non-diabetic subjects. This might have caused some bias in the formation of the diabetic study group. The prevalence of CHD was therefore analyzed separately in subjects with and without diuretics; this showed that the higher prevalence was not explained by the more frequent use of diuretics.

A more than threefold excess in the frequency of digitalis therapy was found among newly-diagnosed diabetic subjects of the present study compared with non-diabetic subjects. Although digitalis therapy does not definitely indicate the existence of left ventricular failure, this strongly suggests that its frequency was markedly increased among diabetic subjects. In addition, diabetic subjects tended to have a higher frequency of cardiomegaly, even though the interpretation of this variable was confounded by digitalis. Nevertheless, subjects using digitalis showed larger relative heart volumes than those not using the drug, giving indirect support to the assumption that most of the subjects treated with digitalis also have depressed left ventricular function. Thus the present results are in accordance with the Framingham Study [13], in which the incidence of heart failure was increased 2.4-fold in male and 5.3-fold in female diabetic subjects.

In addition to CHD and hypertension, a specific heart muscle disorder, diabetic cardiomyopathy, may also be involved in the development of heart failure [35-35]. There is also evidence suggesting that Type 2 diabetic subjects may have left ventricular dysfunction attributable to diabetes itself at the time of diagnosis [36-38].

No significant differences were found in the mean systolic and diastolic blood pressure levels between diabetic and non-diabetic subjects. Comparison of blood pressure levels was, however, confounded by the higher frequency of anti-hypertensive drug therapy among diabetic subjects. When the prevalence of hypertension was compared, by using current use of anti-hypertensive drugs or elevated blood pressure level on examination as criterion, the prevalence of hypertension was increased 1.6-1.7-fold among the diabetic subjects. In addition it was found that the higher prevalence of hypertension could not be ascribed solely to the higher degree of obesity in diabetic patients. Our findings are thus in accordance with those found in studies on newly-diagnosed diabetic patients detected in population studies on the basis of a glucose tolerance test [3, 18, 19]. The mechanisms underlying the high frequency of hypertension in newly diagnosed Type 2 diabetic subjects are not completely understood and, in addition to hyperglycaemia and obesity $[18,19]$, other factors may be involved $[39,40]$.

In conclusion, newly diagnosed Type 2 diabetic patients showed a higher prevalence of CHD and hypertension than the respective non-diabetic subjects. Our results also suggest that the frequency of left ventricular 
failure was increased among these diabetic subjects. The excessive prevalence of these cardiovascular diseases in diabetic patients could not solely be ascribed to obesity.

Acknowledgements. We express our best thanks to Professors J. K. Huttunen and O.P. Heinonen for their valuable help in the planning phase of this study and to Mrs M. Kotilainen, Mrs. L. Uschanoff and Miss E-M.Oittinen for technical assistance. This work was supported by grants from the Medical Research Council of the Academy of Finland.

\section{References}

1. Garcia MJ, McNamara PM, Gordon T, Kannel WB (1974) Morbidity and mortality in diabetics in the Framingham population. Sixteen year follow-up study. Diabetes 23: 105-111

2. Kannel WB, McGee DL (1979) Diabetes and carciovascular disease. The Framingham study. JAMA 241: 2035-2038

3. Herman JB, Medalie JG, Goldbourt U (1977) Differences in cardiovascular morbidity and mortality between previously known and newly diagnosed adult diabetics. Diabetologia 13:229-234

4. Fuller JH, Shipley MJ, Rose G, Jarrett RJ, Keen H (1980) Coronary heart disease risk and impaired glucose tolerance. The Whitehall study. Lancet 1:1373-1376

5. Heyden S, Heiss G, Bartel AG, Hames CG (1980) Sex differences in coronary mortality among diabetics in Evans county, Georgia. $J$ Chron Dis 33: 265-273

6. Jarrett RJ, McCartney P, Keen H (1982) The Bedford survey: tenyear mortality rates in newly diagnosed diabetics, borderline diabetics and normoglycaemic controls and risks indices for coronary heart disease in borderline diabetics. Diabetologia: $22: 79-84$

7. Reunanen A, Laakso M, Pyörälä K (1983) Cardiovascular and coronary heart disease mortality of diabetics and non-diabetics; impact of risk factors. Am Coll Cardiol 2: 600 (Abstract)

8. Pyörälä K (1979) Relationship of glucose tolerance and plasma insulin to the incidence of coronary heart disease: results from two population studies in Finland. Diabetes Care 2: 131-141

9. Stamler R, Stamler J (eds) (1979) Asymptomatic hyperglycemia and coronary heart disease. A series of papers by the international collaborative group based on studies in fifteen populations. $J$ Chron Dis 32: 638-837

10. Jarrett RJ, Keen H, Fuller JH, McCartney M (1979) Worsening to diabetes in men with impaired glucose tolerance ("borderline diabetes'). Diabetologia 16: 25-30

11. Keen H, Rose G, Pyke DA, Boyns D, Chlouverakis C, Mistry S (1965) Blood sugar and arterial disease. Lancet 2: 505-508

12. Weaver JA, Bhalia SK, Boyle D, Haddan DR, Montgomery DAD (1970) Cardiovascular state of newly discovered diabetic women. Br Med J 1: 783-786

13. Kannel WB, Hjortland M, Castelli WP (1974) Role of diabetes in congestive heart failure. Am J Cardiol 34: 29-34

14. Pell S, D'Alonzo CA (1967) Some aspects of hypertension in diabetes mellitus. JAMA 202: 104-110

15. Dupree EA, Meyer MB (1980) Role of risk factors in complications of diabetes mellitus. Am J Epidemiol 112: 100-112

16. Aromaa A (1981) Epidemiology and public health impact of high blood pressure in Finland (Finnish, with English summary). Helsinki: Kansanterveystieteen julkaisuja AL: 17, Helsinki

17. Barrett-Connor E, Criqui MH, Klauber MR, Holdbrook M (1981) Diabetes and hypertension in a community of older adults. Am J Epidemiol 113: 276-284

18. Jarrett RJ, Keen H, McCartney M, Fuller JH, Hamilton PJS, Reid DD, Rose G (1978) Glucose tolerance and blood pressure in two population samples: their relation to diabetes mellitus and hypertension. Int J Epidemiol 7: 15-24

19. Jarrett RJ, Keen H, Chakrabarti R (1982) Diabetes, hyperglycae- mia and arterial disease. In: Keen H, Jarrett RJ (ed) Complications of diabetes, 2nd edn. Edward Arnold, London, pp 179-203

20. WHO Expert Committee on Diabetes Mellitus (1980) Second report. Technical Report Series, No 646, Geneva

21. Laakso M, Honkonen E, Kauppinen U, Pyörälä K (1983) Diagnostic criteria used for the definition of diabetes in the district of University Central Hospital of Kuopio (Finnish). Suom Lääkäril 10: $862-865$

22. Uusitupa M (1983) Coronary heart disease and left ventricular performance in newly-diagnosed non-insulin-dependent diabetics. M.D. academic thesis. University of Kuopio 1983

23. Rose GA (1962) The diagnosis of ischaemic heart pain and intermittent claudication in field surveys. Bull WHO 27: 645-658

24. Arterial hypertension, report of a WHO Expert Committee (1978) Technical Report Series 628, Geneva

25. Rose GA, Blackburn H (1968) Cardiovascular survey methods. WHO Monograph Series No 56, World Health Organization, Geneva

26. Jonsell S (1939) A method for the determination of the heart size by teleroentgenography (a heart volume index). Acta Radiologica 20: $325-340$

27. Reid DD, Brett GZ, Hamilton PJS, Jarrett RJ, Keen H, Rose GA (1974) Cardiorespiratory disease among middle-aged civil servants. A study of screening and intervention. Lancet 1:469-473

28. Armitage P (1980) Statistical methods in medical research. Blackwell, Oxford, pp 384-388

29. Pyörälä K, Punsar S, Reunanen A, Heinonen OP, Puro K, Aromaa A (1974) Social Insurance Institution's coronary heart disease study. Prevalence of chest pain symptoms and ECG findings in nine Finnish population groups (in Finnish with English summary). Kansaneläkelaitoksen julkaisuja AL 1/1975, Helsinki

30. Puska P, Tuomilehto J, Salonen J, Nissinen A, Virtamo J, Björkqvist S, Koskela K, Neittaanmäki L, Takalo T, Kottke T, Mäki J, Sipilä P, Varvikko P (1981) Community control of cardiovascular diseases. The North Karelia project: World Health Organization, Regional Office for Europe, Copenhagen

31. Reunanen A, Aromaa A, Pyörälä K, Punsar S, Maatela J, Knekt P (1983) The Social Insurance Institution's coronary heart disease study. Acta Med Scand Suppl 673

32. Murphy MB, Lewis PJ, Kohner E, Schumer B, Dollery CT (1982) Glucose intolerance in hypertensive patients treated with diuretics; a fourteen-year follow-up. Lancet 2: 1293-1295

33. Regan TJ, Weisse AB (1978) The question of cardiomyopathy in diabetes mellitus. Ann Int Med 89: 1000-1002

34. Ledet T, Neubauer B, Christensen, NJ, Lundbaek K (1979) Diabetic cardiopathy. Diabetologia 16: 207-209

35. Shapiro LM (1982) Specific heart disease in diabetes mellitus. $\mathrm{Br}$ Med J 1: 140-141

36. Shapiro LM, Leatherdale BA, Coyne ME, Fletcher RF, Mackinnon J (1980) Prospective study of heart disease in untreated maturity onset diabetics. Br Heart J 44: 342-348

37. Uusitupa M, Siitonen O, Aro A, Korhonen T, Pyörälä K (1983) Effect of correction of hyperglycemia on left ventricular function in non-insulin dependent (type 2) diabetics. Acta Med Scand 213: 363-368

38. Uusitupa M, Siitonen O, Aro A, Pyörälä K (1982) Echocardiographic evaluation of the left ventricular performance and hypertrophy in newly diagnosed non-insulin-dependent diabetic subjects. Diabetologia 25: 199-200 (Abstract)

39. DeFronzo RA (1981) The effect of insulin on renal sodium metabolism. Diabetologia 21: 165-171

40. Drury PL (1983) Diabetes and arterial hypertension. Diabetologia 24: $1-9$

Received: 24 January 1984

and in revised form: 2 November 1984

Dr. M. Uusitupa

University Central Hospital of Kuopio

SF-70210 Kuopio 21

Finland 